\title{
The life satisfaction level of obese people with depressive disorders compared to healthy individuals
}

\author{
Corresponding author: \\ Elżbieta Holec, MSc, PhD student \\ Department of Psychiatric Nursing, \\ Nicolaus Copernicus University, \\ Collegium Medicum in Bydgoszcz \\ Łukasiewicza 1 St. \\ 85-821 Bydgoszcz, Poland \\ Phone: $+4852585-58-22$ \\ Fax: + 4852 585-58-49 \\ E-mail: elhol2@wp.pl
}

Medical Research Journal 2016;

Volume 1, Number 2, 88-91

10.5603/MRJ.2016.0014

Copyright (C) 2016 Via Medica ISSN 2451-2591

\begin{abstract}
Introduction. This research examines the relationship between obesity and pessimism, a decreased sense of happiness, reduced positive affect,_and a low life satisfaction level.

Objective. To measure the level of life satisfaction of obese people with depressive symptoms in contrast to healthy individuals from the general population, and the relationship between the selected socio-demographic variables and mood disorders, and life satisfaction.

Materials and methods. The study involved 30 healthy subjects (the control group), 30 obese people hospitalised in the Department of General and Endocrine Surgery, and 30 patients with depressive disorders treated in the Department of Psychiatry. The study draws upon a interview questionnaire: the Satisfaction with Life Scale (SWLS), and the Beck Depression Inventory (BDI).

Results. It was found that the level of life satisfaction of respondents from all three groups remained at an average level. The highest level of life satisfaction was achieved in the healthy group, and the lowest in those with depression. On the other hand, the level of life satisfaction of obese people did not substantially diverge from healthy subjects.

Conclusions. The life satisfaction of obese people remained at a similar level to the healthy population. A twoway relationship between depression and obesity was shown among patients with depressive disorders and those with obesity. The higher the level of education, the greater the level of life satisfaction; however, this lessens with age and the intensification of depressive symptoms.

Key words: obesity, life satisfaction, depressive disorders
\end{abstract}

Med Res J 2016; 1 (2): 88-91

\section{Introduction}

Obesity is mostly considered from a medical point of view, regardless of its negative psychosocial consequences [1]. Researchers are increasingly concerned with the quality of life and social interaction of obese people. Obese individuals have been shown to have lower self-esteem, lower levels of social support and poorer mental health. Excessive body weight also has a negative, multidimensional, and significant relationship with the psychological and social functioning of an individual [2]. Life satisfaction is a vital determinant of life quality and is an expression evaluating the general life satisfaction of a particular person in respect of their personal standards $[3,4]$. Obesity, together with a number of other disorders that are usually consequential, have negative effects in many areas of life and may be a factor negatively influencing life satisfaction [5]. The longer an individual has been obese, the greater their ability to cope and adapt to the negative consequences of their condition, and in so doing enabling themselves to better deal with stress and in applying defence mechanisms. As a result, the level of life satisfaction of obese people may be similar to that of healthy individuals of normal weight [2].

We aimed to measure the level of life satisfaction amongst people suffering from obesity, those with depression, and healthy individuals.

\section{Materials and methods}

The study was conducted between March and May 2012. The study protocol was approved by the Bioethics Committee at the Nicolaus Copernicus University in Torun, Collegium Medicum in Bydgoszcz (KB 475/2011), 
and complied with the Helsinki Declaration regarding ethical conduct in medical research. All patients gave informed, written consent.

The study involved a total of 90 men and women aged 19-71 years, who were divided into three groups: obese individuals (22 female and 8 male), 30 individuals with depressive disorders (21 female and 9 male ), and finally 30 healthy individuals ( $27 \mathrm{fe}-$ male and 3 male).

The healthy group largely comprised employees of the Department of Psychiatry, the obese group was from the Department of General and Endocrine Surgery. Those with depressive disorders were also patients of the Department of Psychiatry. The study was conducted by means of a questionnaire in order to elicit sociodemographic and clinical data: the Satisfaction with Life Scale (SWLS) by Diener et al. [3], adapted to Polish by Ogińska-Bulik and Juczyński [4]; and the Beck Depression Inventory (BDI) by Beck, with Polish adaptations by Parnowski and Jernajczyk [6-8].

\section{Statistical analysis}

For statistical analysis the following tests have been applied: Chi-squared test, t- Student test, and the correlation analysis of Spearman ranks from the statistical package Statistica. The statistical significance of variables was expressed at $p \leq 0.05$.

\section{Results}

The initial stage of result analysis evaluated clinical variables such as depression (according to the BDI scale) and somatic problems, as well as body mass index (BMI), in the three groups, healthy subjects, obese individuals, and those with depressive disorders (Tab. 1).

Those individuals suffering from depression were statistically older than other subjects (49 years old compared to 41 or 42 years old, respectively). Compared to individuals from the obese and depressed groups, the healthy individuals were usually better educated.

A statistically significant difference among these groups relating to marital status and their places of residence was not observed.

In the healthy group there were two individuals (7\%) with symptoms of depression, in the obese group over $53 \%$ suffered from depression, and among the group of patients in the Department of Psychiatry, all displayed symptoms of depression according to the BDI scale. $23 \%$ of healthy subjects, $76 \%$ of people with depression, and $95 \%$ of obese patients, respectively, suffered from somatic diseases. As expected, the differences in BMI proved to be statistically significant $(p<0.05$ ). The lowest BMI characterised people from the general population (BMI $=22.85,87 \%$ of whom had normal body mass). Subjects with depression had an average BMI of 26.54 and were therefore overweight. In this group $30 \%$ had normal body mass and $46 \%$ were overweight.

Table 1. Comparison of the frequency of depression, somatic problems, and changes of body weight and BMl in all respondents: healthy subjects from the general population, those suffering from depression, and those suffering from obesity

\begin{tabular}{lccc}
\hline Variables & $\begin{array}{c}\text { Healthy subjects } \\
(\mathbf{n}=\mathbf{3 0 )}\end{array}$ & $\begin{array}{c}\text { Depressive individuals } \\
(\mathbf{n}=\mathbf{3 0})\end{array}$ & $\begin{array}{c}\text { Obese individuals } \\
(\mathbf{n}=\mathbf{3 0})\end{array}$ \\
\cline { 2 - 4 } & Group 1 & Group 2 & Group 3 \\
\hline $\begin{array}{l}\text { (According to BDI scoring) } \quad \text { Without depression } \\
\quad \text { With depression }\end{array}$ & $28(93.3 \%)$ & $0(0.0 \%)$ & $14(46.7 \%)$ \\
Reported somatic diseases & $2(6.7 \%)$ & $30(100 \%)^{\mathrm{a}}$ & $16(53.3 \%)^{\mathrm{b}}$ \\
$\quad$ Yes & $7(23.3 \%)$ & $23(76.7 \%)$ & $28(95.4 \%)^{\mathrm{c}}$ \\
$\quad$ No & $23(76.7 \%)$ & $7(23.3 \%)$ & $2(6.6 \%)$ \\
BMI & $22.85 \pm 1.80$ & $26.54 \pm 4.39 \mathrm{e}$ & $43.56 \pm 9.16^{\mathrm{d}}$ \\
Underweight & $0(0.0 \%)$ & $1(3.3 \%)$ & $0(0.0 \%)$ \\
Proper weight & $26(86.7 \%)$ & $9(30.0 \%)$ & $0(0.0 \%)^{\mathrm{d}}$ \\
Overweight & $4(13.3 \%)$ & $14(46.7 \%)$ & $0(0.0 \%)^{\mathrm{e}}$ \\
I stage of obesity & $0(0.0 \%)$ & $5(16.7 \%)$ & $3(10.0 \%)$ \\
II stage of obesity & $0(0.0 \%)$ & $1(3.3 \%)^{\mathrm{e}}$ & $10(33.3 \%)$ \\
III stage of obesity & $0(0.0 \%)^{\mathrm{e}}$ & $0(0.0 \%)^{\mathrm{e}}$ & $17(56.7 \%)^{\dagger}$ \\
\hline
\end{tabular}

a - difference between group 1 and 2 statistically characteristic, chi-square test, $p<0.05$

$\mathrm{b}$ - difference between group 1 and 3 statistically characteristic, chi-square test $p<0.05$

c - difference between group 2 and 3 statistically characteristic, chi-square test $p<0.05$

$d$ - difference between group 1 and 3 statistically characteristic, t-student test, $p<0.05$

e - difference between group 2 and 3 statistically characteristic, student test, $p<0.05$

$\mathrm{f}$ - difference between group 2 and 3 statistically characteristic, t-student test, $p<0.05$ 
Table 2. Comparison of average points of SWLS scale for three respondent groups: healthy subjects, depressive individuals, and obese individuals

\begin{tabular}{lccc}
\hline Variables & $\begin{array}{c}\text { Healthy subjects } \\
(\mathbf{n}=\mathbf{3 0})\end{array}$ & $\begin{array}{c}\text { Depressive individuals } \\
(\mathbf{n}=\mathbf{3 0})\end{array}$ & $\begin{array}{c}\text { Obese individuals } \\
\mathbf{( n = 3 0 )}\end{array}$ \\
\cline { 2 - 4 } & Group 1 & Group 2 & Group 3 \\
\hline SWLS (scoring) & $22.30 \pm 5.40$ & $12.20 \pm 4.76^{\mathrm{a}}$ & $19.30 \pm 6.95^{\mathrm{b}}$ \\
Low results SWLS & $5(16.7 \%)$ & $26(86.7 \%)^{\mathrm{c}}$ & $10(33.3 \%)$ \\
Average results SWLS & $12(40.0 \%)$ & $4(13.3 \%)$ & $8(26.7 \%)$ \\
Low results SWLS & $13(43.3 \%)$ & $0(0.0 \%)$ & $12(40.0 \%)^{d}$ \\
\hline
\end{tabular}

a - difference between group 1 and 2 statistically characteristic, t-student test, $p<0.05$

$\mathrm{b}$ - difference between group 2 and 3 statistically characteristic, t-student test, $p<0.05$

$c$ - difference between group 1 and 2 statistically characteristic, chi- square test, $p<0.05$

$\mathrm{d}$ - difference between group 2 and 3 statistically characteristic, chi-square test $p<0.05$

Among obese subjects with an average BMI of 43; $10 \%$ suffered from first-stage obesity, $33 \%$ from second-stage obesity, and 57\% from third-stage obesity.

Further data analysis evaluated the level of life satisfaction with an SWLS questionnaire in groups of healthy, depressive, and obese individuals (Tab. 2).

The highest life satisfaction level was observed in healthy subjects (with a mean of 22.3 points, average life satisfaction) followed by obese subjects (with a mean of 19.3 points, average life satisfaction). The lowest life satisfaction level was seen in individuals with depressive disorders (with a mean of 12.2 points, low life satisfaction). Low results (1-4 sten) were noted in 41 subjects $(45.6 \%)$, and included 5 healthy subjects (16.7\%), 26 depressive individuals (86.7\%), and 10 obese individuals (33.3\%). High levels (7-10 sten) were present in 25 subjects $(27.8 \%), 13$ of whom (43.3\%) were healthy and none of whom suffered with depressive disorders, although 12 (40\%) were obese.

Table 3 shows a statistically negative correlation between age categories and the intensity and level of life satisfaction, as well as a positive correlation between the level of education and level of life satisfaction.

\section{Discussion}

Our study highlighted the differences in life satisfaction levels (LSL) between different groups of individuals, where the highest level of satisfaction was seen in healthy individuals and the lowest in those suffering from depression. LSL in obese subjects was comparable to that enjoyed by healthy individuals. Kowalski et al., in a Polish study, similarly failed to show statistically significant differences in LSL and in overall quality of life when comparing obese individuals to the general population. However, differences in particular aspects of life quality have been noted; overweight individuals were characterised as having higher self-esteem in
Table 3. Spearman coefficient correlation in all 90 subjects with regard to their age ranges and occurrence of depressive symptoms, together with their education status and their levels of life satisfaction

\begin{tabular}{lcc}
\hline Variables & \multicolumn{2}{c}{$\begin{array}{c}\text { The level of life } \\
\text { satisfaction according } \\
\text { to SWLS scale } \\
\text { (low, average, high) }\end{array}$} \\
\cline { 2 - 3 } & $\mathbf{r}$ & $\mathbf{p}$ \\
\hline $\begin{array}{l}\text { Age (ranges: < 40; 41-50; > 50 } \\
\text { years old) }\end{array}$ & -0.346 & 0.001 \\
$\begin{array}{l}\text { Depressive symptoms (without } \\
\text { depression, mild, and high } \\
\text { depression - according to BDI scale) }\end{array}$ & -0.739 & 0.0001 \\
$\begin{array}{l}\text { Education (primary, vocational, } \\
\text { secondary, higher) }\end{array}$ & 0.358 & 0.0001 \\
\hline
\end{tabular}

areas not related to physical appearance, avoiding in this way negative perceptions of themselves [9]. Obese subjects rated more highly their personal, family, and financial status rather than their physical appearance, whilst individuals with normal BMI rated their physical condition more highly because obesity is associated with numerous negative social and health consequences [9]. In other studies, obesity was reflected in individuals having a less positive frame of mind and lower levels of happiness and life satisfaction [10]. BMI has practically no direct influence on life satisfaction, but it affects it indirectly in lowering an individual's self-esteem regarding their physical appearance. So, in this respect, BMI directly causes an increase in levels of life satisfaction [11]. It can be argued that the longer the period of time that a person is overweight, the greater the ability that individual has to adjust or even become resistant to negative aspects concerning their obesity, for example by applying self-defence mechanisms and developing individual means of coping with stress [2]. In our study we demonstrated that obese individuals 
mainly consisted of patients who have been suffering with excessive body mass for several years and may have had a positive influence on perceived levels of life satisfaction. Our results showed that depressive subjects with the lowest levels of life satisfaction also had lower levels of education and were generally older than in other groups. Therefore, we suggest that as well as emotional status, age and education affect levels of life satisfaction.

It was shown that depressive subjects are more likely to be overweight, and in turn, obese individuals may experience depressive symptoms, suggesting a mutual correlation between these two conditions.

From a practical point of view, recognising the level of life satisfaction amongst depressive and obese subjects could be a significant determinant relating to their quality of life and health problems, but higher education and the lack of depressive symptoms may be viewed as factors contributing to higher levels of life satisfaction.

\section{Conclusions}

1. The lowest level of life satisfaction (SWLS) was shown in depressive subjects, whereas levels for obese and healthy individuals were comparable.

2. A positive correlation was shown between education and sten values of SWLS scale and a negative correlation between age and depression.

3. There was an increased frequency of depression amongst obese subjects and conversely obesity amongst depressive individuals, suggesting mutual correlation between these two conditions.

\section{Conflict of interest}

The authors state that there are no conflicts of interest regarding the publication of this article.

\section{References}

1. Makara-Studzińska M, Gałkiewicz M. Psychospołeczne aspekty otyłości. Ann UMCS Sect D 2003; 58: 280-285.

2. Chanduszko-Salska J, Chodkiewicz J. Zadowolenie z życia a poczucie własnej skuteczności, wsparcie społeczne oraz stan zdrowia u Kobiet z nadwagą i otyłością. Endokr, Otyłość i Zab Przem Mat 2010; 4: 171-178.

3. Juczyński Z. Narzedzia pomiaru w promocji i psychologii zdrowia Pracownia Testów Psychologicznych Polskiego Towarzystwa Psychologicznego. Warszawa 2001.

4. Ogińska-Bulik N, Juczyński Z. Osobowościowe wyznaczniki satysfakcji z życia. In: Heszen I, Życińska J (eds.). Psychologia zdrowia w poszukiwaniu pozytywnych inspiracji. Wyd. SWPS Academica, Warszawa 2008: 89-100.

5. Jakubowska E, Jakubowski K, Cipora E. Satysfakcja z życia chorych z cukrzycą. Probl Hig Epidemiol 2010; 91: 308-313.

6. Parnowski T, Jernajczyk W. Inwentarz Depresji Becka w ocenie nastroju osób zdrowych i chorych na choroby afektywne. Psychiatria Pol 1977; 4: 417-421.

7. Beck AT, Ward $\mathrm{CH}$, Mendelson M. Mock for measuring depression. Arch Gen Psychiat 1961; 4: 53-63.

8. Wciórka J. Pużyński S. Narzedzia oceny stanu psychicznego. In: Rybakowski J, Pużyński S, Wciórka J (eds.). Psychiatria. Elsevier Urban \& Partner, Wrocław 2010: 413-476.

9. Bertrandt K. Samoocena a jakość życia i występowanie objawów depresyjnych u osób z nadwagą i otyłością porównaniu z osobami o prawidłowej masie ciała. Probl Hig Epidemiol 2011; 92: 783-787.

10. Markowitz S, Friedman MA, Shawn MA. Understanding relationship between obesity and depression: casual mechanisms and implications for treatment. Clin Psychol-Sci Pr 2008; 15: 1-20.

11. Gruszczyńska E, BazylukET. Zależność miedzy masa ciała a satysfakcją z życia wśród dziewcząt w okresie późnego dorastania o wadze zgodnej z normą. Studium eksploracyjne. Psychologia Jakości Życia 2007; 1: 17-32. 